\title{
The basic foundations of Capoeira learning from 5 to 10 years of age: implementation and evaluation of a formative project
}

\author{
Nelson BARROS*1,2, Marco A. C. BRANC01,3,4, David CATELA ${ }^{1,3,4}$ \\ ${ }^{1}$ Sport Sciences School of Rio Maior - Polytechnic Institute of Santarém (Portugal) \\ ${ }^{2}$ Portuguese Federation of Capoeira- FPCAPOEIRA (Portugal) \\ ${ }^{3}$ Quality of Life Research Center (Motor Behavior)- CIEQV (Portugal) \\ ${ }^{4}$ Polytechnic Institute of Santarém Research Unity(Motor Behavior)-UIIPS (Portugal)
}

\section{Introduction}

Capoeira differs from the vast majority of other duels by the musical accompaniment, where the rhythm gives the temporal structure to the movement. The practice of Capoeira enables the development of structural elements of human movement, particularly in perception-action cycles, e.g., music rhythm and specific movements or peripheral vision and attack and defense actions, integrated in cultural and socio-affective dimensions (Silva \& Damiani, 2005). The training in Capoeira follows a traditional course in associations or Capoeira groups where transmission of knowledge is made by the Mestre de Capoeira, each developing an individual philosophy and methodology and based on accumulated practical knowledge. Actually, there is no formal process and specific training of these professionals, and professionals usually have little qualification. The practitioner student passes to teacher condition by subjective criteria (Heine, Carbinatto, \& Nunomura, 2009). In order to contribute to a tested contents' systematization, for the motor learning of the basis of Capoeira, in the 2nd childhood, considered the critical period of development of motor skills and coordinative abilities (Mitra \& Mogos, 1990), as well as structuring modes social interaction (Ré, 2011), the authors started a project to build and test a guiding program for Capoeira teaching agents, for them to structure and sustain the progression of learning the basic techniques, tactics and rules; as well as to introduce to the process of interaction between capoeiristas performers and instrumentalists, while respecting the cultural and historical values of Capoeira' identity.

\section{Project structure}

The sample will be composed of beginner children, of both genders, aged between 5 and 10 years old, a critical period of development of sense of rhythm and of motor and coordinative skills (Clark, 1994; Clark \& Metcalfe, 2002). These children belong to a non-governmental organization, with social integrative roles. The purpose of the project is to provide a process of motor learning that affords the acquisition of specific and essential techniques, more than technical improvement (Falcão, 2004). In a pre- post-test study, the intervention program will emphasize the preservation of cultural identity elements, such as rhythmic structure, and participants' spatial organization and roles (Alleoni, 2010); and, a playful dimension will be ensured in the dialogue among the diverse actors involved in the Roda (Heine, Carbinatto, \& Nunomura, 2009b). This means that the opportunity to deliberate practice and deliberate play should be preserved, especially with the possibility of movement of free exploration (Reis, 1994). The movements must be synchronized with specific rhythms (Heine, Carbinatto, \& Nunomura, 2009). The learning of specific motor skills must be based on structural movement Ginga (Netto, 2007). The proposed content was initially

*Email: nelson.ar.barros@gmail.com 
based on the systematization of Souza and Oliveira (2008), from how we selected, defined, and organized a set of basic contents, divided into two dimensions: i) the covering of cultural and historical roots; such as instruments, music and rituals; and ii) the acquisition of specific motor skills, divided in the following categories: specialized, transitional, and tactics. Informed consent from the parents and assent from the children will be obtained. Principles of the Helsinki Treaty will be respected. The project will be submitted to the ethics committee of UIIPS.

Capoeira area will consist of three concentric circles, established on hard floor, not slippery, defined as follows: i) Red - security area, radius $2.30 \mathrm{~m}$; ii) Yellow - half play area and long-distance, radius $1.50 \mathrm{~m}$; iii) Green - half play area and walking distances, radius of $1.20 \mathrm{~m}$.

This project is conceived as a longitudinal study, quasi-experimental, pre post-test, in which the participant is control of himself. Evaluation will be made at three levels: i) quality of basic movement Ginga; ii) synchronization among Capoeira players, in the Roda; and, iii) knowledge of basic rhythmic structure. The qualitative evaluation of the motor execution of Ginga, will be based on nominal dichotomous observation grids, with facial validation by an expert panel (e.g., Brennecke, Amadio, \& Serrão, 2005).For analysis of synchronization among players, markers will be placed in anatomical references in the body of each participant, and APAS movement analysis program will be used, with support of a calibration cube with markers, a fix point, and, three cameras $(30 \mathrm{~Hz})$. For the analysis of rhythmic structuring, the replication with palms of Capoeira basic rhythmic sequences will be analyzed through sound digital registration. For the analysis of capability of child' synchronization with the other, in Ginga, and the in palms rhythm, the nonlinear Cross Recurrence Analysis (CRQA) method will be used. For statistical analysis we use the Statistical Package for Social Sciences (SPSS), version 20.0. We will make exploratory data analysis, in order to evaluate the normality of distribution, using the Shapiro-Wilk test. McNemar e Wilcoxon tests will be used for comparing moments of evaluation. The significance level for all statistical tests was set at $p \leq 0.05$.

\section{References}

Alleoni, B. N. (2010). A Manifestação Corporal Capoeira: Uma Cultura Nacional Brasileira. / the Corporal Manifestation Capoeira: A Brazilian National Culture. Revista Mackenzie de Educacao Fisica E Esporte, 9(1), 24-31.

Brennecke, A., Amadio, A. C., \& Serrão, J. C. (2005). Parâmetros dinâmicos de movimentos selecionados da Capoeira. Revista Portuguesa de Ciências do Desporto, Porto, 5(2), 153-159.

Clark, J.E. (1994). Motor development. In V.S. Ramachandran (Ed.), Encyclopedia of human behavior (vol. 3, pp. 245-255). New York: Academic Press.

Clark, J. E., \& Metcalfe, J. S. (2002). The mountain of motor development: A metaphor. In J.E. Clark \& J. Humphrey (Eds.), Motor development: Research and reviews, Vol. 2. (pp. 163 - 190). NASPE Publications: Reston, VA.

de Souza, S. A. R., \& de Oliveira, A. A. B. (2008). Estruturação da capoeira como conteúdo da educação física no ensino fundamental e médio. Revista Da Educação Física/UEM, 12(2), 43-50.

Falcão, J. L. C. (2004). O jogo da capoeira em jogo e a construção da práxis capoeirana. Salvador, Brasil: Universidade Federal da Bahia.

Heine, V., Carbinatto, M. V., \& Nunomura, M. (2009). Estilos de ensino e a iniciação da capoeira para crianças de 7 a 10 anos de idade. Pensar a Prática, 12(1), 1-13.

Mitra, G., \& Mogos, A. (1990). O Desenvolvimento das Qualidades Motoras no Jovem Atleta. Lisboa: Livros Horizonte.

Netto, N. S. P. A. (2007). A capoeira no município de campo largo, estado do Paraná: uma experiência educacional a partir da abordagem crítico-superadora em educação física escolar. In: VII Congresso Nacional de Educação - EDUCERE. (Anais) (pp. 2294-2306). Pontifícia Universidade Católica do Paraná - PUC-PR. Curitiba: 2007. Retrieved from http://www.pucpr.br/eventos/educere/educere2007/anaisEvento/arquivos/CI-301-05.pdf

Silva, A. M., \& Damiani, I. R. (2005). Práticas corporais. Florianapolis: Nauemblu ciência \& arte.

Keywords: Capoeira; initiation; foundations; development; capacities; martial arts; combat sports. 